\title{
Native Trichoderma grown on oat grains controls damping-off and enhances height in soybean ${ }^{1}$
}

\author{
Alexandre Dinnys Roese ${ }^{2}$, Gloria Soriano Vidal ${ }^{2}$, \\ Erica Camila Zielinski², Louise Larissa May De $\mathrm{Mio}^{2}$
}

\section{ABSTRACT}

Trichoderma is a biological control agent used to improve the resistance to diseases, which may also estimulate plant growth. Commercial products with Trichoderma are available in different countries, but most of them are based on conidial suspension. This study aimed at evaluating the efficiency of native Trichoderma populations collected from different production systems and applied to the soil by using two methods: conidial suspension and inoculated oat grains. The efficiency of native Trichoderma populations collected from conventional crop and agropastoral and agrosilvopastoral systems in a long-term field experiment was evaluated. The populations efficiencies were evaluated by in vivo tests that assessed the control of soybean damping-off caused by Rhizoctonia solani, plant height and soil colonization with the antagonist. In vitro tests, such as dual culture and assessment of volatile and non-volatile compounds, were conducted to study the mode of action of the populations. Some native Trichoderma populations were as efficient as those from a commercial product in all tests. Compared to conidial suspension, Trichoderma spp. inoculated through oat grains promoted a greater damping-off control, higher plants and more colony-forming units per gram of soil after 3 months of application. Native populations performed equally well or even better than the commercial strain, and the use of a substrate that supports the Trichoderma growth was more efficient than the conidial suspension method.

KEYWORDS: Rhizoctonia solani; Avena L.; soil infestation.

\section{INTRODUCTION}

Trichoderma spp. Pers., a generalist biological control agent, is antagonist to various pathogens. It may also stimulate plant growth and improve plant resistance to diseases (Verma et al. 2007, Lorito et al. 2010). It is recovered from soils around the world and from different production systems (Lorito et al. 2010, Khalili et al. 2012). Trichoderma is also

\section{RESUMO}

Trichoderma nativo cultivado em grãos de aveia controla o tombamento e aumenta a altura da soja

Trichoderma é um agente de controle biológico utilizado para melhorar a resistência a doenças, que também pode estimular o crescimento de plantas. Produtos comerciais com Trichoderma estão disponíveis em diversos países, mas a maioria baseia-se na suspensão de conídios. Objetivou-se avaliar a eficiência de populações nativas de Trichoderma coletadas de diferentes sistemas de produção e aplicadas ao solo por dois métodos: suspensão de conídios e grãos de aveia infestados. Avaliou-se a eficiência de populações de Trichoderma coletadas de lavoura convencional e sistemas agropastoril e agrossilvopastoril, em experimento de campo de longa duração. A eficiência foi avaliada por testes in vivo, analisando-se o controle de tombamento de soja causado por Rhizoctonia solani, a altura das plantas e a colonização do solo com o antagonista. Os testes in vitro de pareamento de culturas, compostos voláteis e não voláteis foram realizados para explicar o modo de ação das populações. Algumas populações de Trichoderma nativas foram tão eficientes quanto a obtida de produto comercial, em todos os testes. Com grãos de aveia infestados, Trichoderma spp. promoveu maior controle de tombamento, maior altura de plantas e mais unidades formadoras de colônias por grama de solo após três meses da aplicação, quando comparado com a suspensão de conídios. Populações nativas foram igualmente boas ou mesmo melhores do que a cepa comercial, e a utilização de um substrato que suporta o crescimento de Trichoderma foi mais eficiente do que a suspensão de conídios.

PALAVRAS-CHAVE: Rhizoctonia solani; Avena L.; infestação do solo.

relatively easy to cultivate, as it can multiply within a considerable range of $\mathrm{pH}(5.5-7.5)$ and temperature (20-35 $\left.{ }^{\circ} \mathrm{C}\right)$ (Singh et al. 2014).

Commercial products containing Trichoderma strains are available in different countries and regions (Woo et al. 2014), and this genus is responsible for natural or induced suppressiveness to several plant pathogens in the soil (Weller et al. 2002, Janvier et al. 2007).

1. Manuscript received in Aug./2016 and accepted for publication in Mar./2017 (http://dx.doi.org/10.1590/1983-40632016v4742966).

2. Universidade Federal do Paraná, Departamento de Fitotecnia e Fitossanitarismo, Curitiba, PR, Brazil.

E-mails: alexandre.roese@embrapa.br, gloriavidal22@gmail.com, ericacamilazielinski@gmail.com, maydemio@ufpr.br. 
Woo et al. (2014) identified 250 commercially available Trichoderma products, with most of them being based on conidial suspension (wettable powder, granular and liquid formulations). Only $6.2 \%$ of the surveyed products were based on substrates that support the Trichoderma growth.

There are various ways of producing and using biological control agents, which can influence their effectiveness in colonizing the soil and controlling diseases (Marín-Guirao et al. 2016). According to Harman et al. (2010), the local production of biological control products has some advantages: a) the biological control agent strains are isolated from the area where they will be used, what may facilitate their adaptation and persistence in the soil system; b) they can be cultivated by farmers in a well-known and easy way; c) they can be grown in time for use, ensuring freshness and eliminating the costs of transportation and storage.

Trichoderma spp. is commonly found in well conserved and healthy soils (Liu et al. 2008, Garbisu et al. 2011, Larkin 2015). Achieving healthy soils with a capacity to suppress diseases is an objective of the integrated crop-livestock system, a longstanding production system considered as the main form of agricultural land use in the world (Bell \& Moore 2012). It is expected that Trichoderma plays an important role in suppressing pathogens in complex soil environments.

Based on the availability of Trichoderma strains in the soil and the fact that the majority of commercial products are based on conidial suspension to be applied on the soil, the following questions are addressed in this research: a) Do farms have efficient populations of Trichoderma in their soil, which can be used for biological control?; b) Is the current predominant method of applying Trichoderma on the soil the best way to control diseases and colonize the soils? To answer these questions, six Trichoderma populations, collected from soils under conventional cropping and two integrated crop-livestock systems, were compared with a commercial strain. Native Trichoderma populations were compared to the commercial strain using two methods of application to the soil: conidial suspension and inoculated oat grains. The damping-off of soybean caused by Rhizoctonia solani J.G. Kühn was used as a disease model to evaluated the effectiveness of the Trichoderma populations in suppressing pathogens.

\section{MATERIAL AND METHODS}

Thirty Trichoderma populations were collected from soil samples in a long-term integrated croplivestock system field experiment installed in 2006, in Ponta Grossa, Paraná State, Brazil $\left(25^{\circ} 07^{\prime} \mathrm{S}\right.$, $50^{\circ} 03^{\prime} \mathrm{W}$ and altitude of $953 \mathrm{~m}$ ). The field experiment comprised the following production systems, in order of increasing complexity: conventional crop, agropastoral and agrosilvopastoral systems. The crop sequence in all the systems consisted of soybean (Glycine max) and corn (Zea mays), in alternating summer seasons, and a consortium of black oat (Avena strigosa) and annual ryegrass (Lolium multiflorum) every winter. In the agropastoral system, cattle grazing occurs for 3 months, over the winter pastures. In the agrosilvopastoral system, besides cattle grazing, crops and forages are sown in alleys. The tree components of the alleys consisted of eucalyptus (Eucalyptus dunnii) and silver oak (Grevillea robusta), alternating in single rows, with $3 \mathrm{~m}$ between trees and $14 \mathrm{~m}$ between rows.

Six soil samples (0-15 cm layer) were randomly collected in November (2014) from conventional crop plots, 12 samples from agropastoral plots and 12 samples from agrosilvopastoral plots. Samples were taken with the aid of a shovel, collecting a block of soil with uniform width, from the surface to $15 \mathrm{~cm}$ deep. The soil was packed in plastic bags to retain moisture and, on the following day, was passed through a sieve (1 mm opening) and submitted to a serial dilution with tap water, to isolate the Trichoderma populations on potato-dextrose-agar (PDA) medium. One Trichoderma population was isolated from each soil sample. Genus confirmation was performed by examining the morphological characteristics of colonies, hyphae, conidia and conidiophores under light microscopy. Two populations from each production system were selected, based on their ability to grow and produce spores on weak PDA (20\% of PDA concentration), with $0.08 \%$ lactic acid added. The Rhizoctonia solani inoculum was obtained from soybean plants expressing damping-off symptoms and produced according to Kinsbursky \& Weinhold (1988), multiplying in oat grains and chopping to $1 \mathrm{~mm}$ diameter after drying.

The six native populations selected, plus a strain of $T$. harzianum obtained from a commercial product and a control without antagonist, were compared in pot cultures with five replicates. The 
ability of each strain to control the soybean dampingoff caused by $R$. solani was assessed in a completely randomized design, using two methods of soil infestation with the antagonist.

In the first experiment, performed during the $2014 / 2015$ crop season, a conidial suspension of each population was prepared, following the final concentration recommended for the commercial product application $\left(25 \times 10^{6}\right.$ conidia $\left.\mathrm{mL}^{-1}\right)$. The conidia concentration was determined using a hemacytometer. Each pot contained 1.5 L of soil, onto which the suspensions were distributed, followed by irrigation avoiding water runoff. The control treatment without antagonist received only water.

In the second experiment, performed during the $2015 / 2016$ crop season, $1.0 \mathrm{~g}$ (equivalent to 0.5 ton $\mathrm{ha}^{-1}$ ) of black oat grains inoculated with each Trichoderma population was mixed into the first $5 \mathrm{~cm}$ depth of soil, followed by irrigation avoiding water runoff. The control without antagonist received only sterile oat grains. The oat grains were double autoclaved before being inoculated with Trichoderma populations. No attempts to quantify the conidia densities in the grains were made. Differences in the initial conidia densities may have occurred, as a characteristic of the growth ability of each population. The soil used in these experiments was an Anthrosol with $31 \mathrm{~g} \mathrm{dm}^{-3}$ of organic carbon, previously pasteurized for $8 \mathrm{~h}$. The same $R$. solani and Trichoderma spp. isolates were used in the experiments with both methods of soil inoculation. Irrigation was performed manually in each pot, avoiding any soil drying or soaking.

In both experiments, the soil was firstly inoculated with the pathogen. Trichoderma populations were applied to the soil in the following week. After another week, soybean was sown three times consecutively, in order to allow for a longer period of interaction between the antagonist and the pathogen in the soil, and also to increase the amount of data acquired. Evaluations of disease incidence were carried out at 25 days after each sowing. Evaluations of plant height were made only after the third sowing, at the same day of the damping-off evaluation.

After the last disease evaluation, a dilution plate count technique (Vargas Gil et al. 2009) was performed, taking $10 \mathrm{~g}$ of soil from each pot and diluting them in $90 \mathrm{~mL}$ of tap water. After agitation for $90 \mathrm{~min}$ at $170 \mathrm{rpm}$, a serial dilution was made to $1 \mathrm{~g} \mathrm{~L}^{-1}$. Following this, $500 \mu \mathrm{L}$ of the dilutions were spread on weak PDA with $0.08 \%$ lactic acid added, with three Petri dishes per sample. The dishes were kept in the dark at room temperature and the number of colonies per dish was counted after five days. All in vivo and soil colonization tests were made in duplicate. Data from the two duplicates were considered as replicates and evaluated together.

To elucidate the mode of action of efficient populations against $R$. solani, the six native populations and the commercial strain were tested by dual culture (Dennis \& Webster 1971) on PDA, in $90 \mathrm{~mm}$ Petri dishes, with four replicates. These were compared with a control without the antagonist. Plugs of $5 \mathrm{~mm}$ diameter of seven-day-old $R$. solani were transferred to Petri dishes, $1 \mathrm{~cm}$ from the edge. On the next day, plugs of $5 \mathrm{~mm}$ diameter of five-dayold Trichoderma populations were transferred to the opposite side of the dish. After three more days, the two opposite diameters of $R$. solani colonies were measured, in order to obtain the average diameter of the colony, discounting the initial pathogen size.

The efficiency in controlling $R$. solani by volatile compounds (Dick \& Hutchinson 1966) was tested by transferring one plug of $5 \mathrm{~mm}$ diameter of the pathogen to the internal side of a $90 \mathrm{~mm}$ Petri dish cover containing PDA, and one plug of $5 \mathrm{~mm}$ diameter of Trichoderma spp. to the base of the same Petri dish containing PDA, with four replicates. Plates were sealed taking care to maintain at least $1 \mathrm{~cm}$ between pathogen and antagonist plugs. After three days, a double diameter of the pathogen colony was measured and the treatments compared. The test for controlling $R$. solani by non-volatile compounds (Dennis \& Webster 1971) was also carried out in $90 \mathrm{~mm}$ Petri dishes with four replicates, using sterile cellophane on the PDA, where plugs of $5 \mathrm{~mm}$ diameter of five-day-old Trichoderma populations were placed and left for two days. After this, the cellophane with Trichoderma spp. was removed and plugs of $5 \mathrm{~mm}$ diameter of seven-day-old $R$. solani were placed in the center of each dish. Three days later, a double diameter of the pathogen colony was measured and the treatments compared. All the in vitro tests were conducted under a completely randomized design. Experiments were installed in incubator chambers at $25 \pm 1{ }^{\circ} \mathrm{C}$, with $12 \mathrm{~h}$ of fluorescent light per day.

Statistical inferences of damping-off were performed by fitting a generalized linear mixed model with binomial sampling distribution, logistic link, and random effects assigned to the experimental units. A 
similar generalized linear mixed model structure was used for the colony forming units recovered from the soil, with a Poisson distribution for the response variable.

Statistical inferences of soybean plant height, dual culture and volatile and non-volatile compounds were performed by fitting a linear model with Gaussian sampling distribution assigned to the experimental units. When necessary for analysis of variance, data were transformed using the boxcox function of the package MASS (Venables \& Ripley 2002) and then inversely transformed to express the results.

For all the in vivo and soil colonization experiments, treatment comparisons were performed by contrasting the effects of Trichoderma population with a 0.05 global significance level. Multiple comparisons were performed by the single-step method, using the function glht() from the R' package multcomp (Hothorn et al. 2008). For dual culture and assessment of volatile and non-volatile compounds, treatment comparisons were performed by the Duncan's test $(\mathrm{p} \leq 0.05)$. Statistical analyses were performed using the R software (R Core Team 2015) and the add-on packages latticeExtra (Sarkar \& Andrews 2013), lme4 (Bates et al. 2014), multcomp (Hothorn et al. 2008) and ExpDes (Ferreira et al. 2003). A joint analysis of the distinct experiments was performed to compare the soil infestation method with Trichoderma spp. on damping-off control, plant height and soil colonization with the antagonist.

\section{RESULTS AND DISCUSSION}

The six native populations and the commercial strain reduced the proportion of damping-off symptoms when applied to the soil by conidial suspension, even though the average control was low (14\% reduction). With inoculated oat grains, the populations AP12 and ASP24 and the commercial strain controlled the disease with averages of $31 \%$, $29 \%$ and $27 \%$, respectively (Figure 1). However, the confidence intervals indicate that this reduction is not significant. The antagonism of Trichoderma to $R$. solani is well documented (Weller et al. 2002), with the best strains achieving more than $50 \%$ of mycelia growth inhibition (Mischke 1997), and approximately $40-100 \%$ control of sclerotia germination in vitro (Grosch et al. 2006).

In this study, soybean plant height was not affected by the conidial suspension of any Trichoderma population. On the other hand, after inoculated oat grains were applied to the soil, all populations enhanced plant height, when compared to the control without the antagonist (Figure 2). This result could be caused by both the active growth of Trichoderma spp. in the substrate or to the amount of conidia in the oat
Conidial suspension

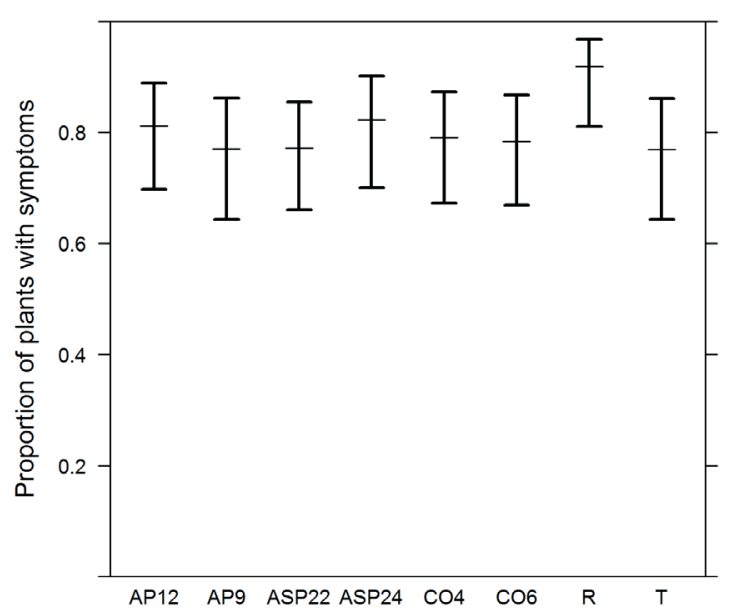

Inoculated oat grains

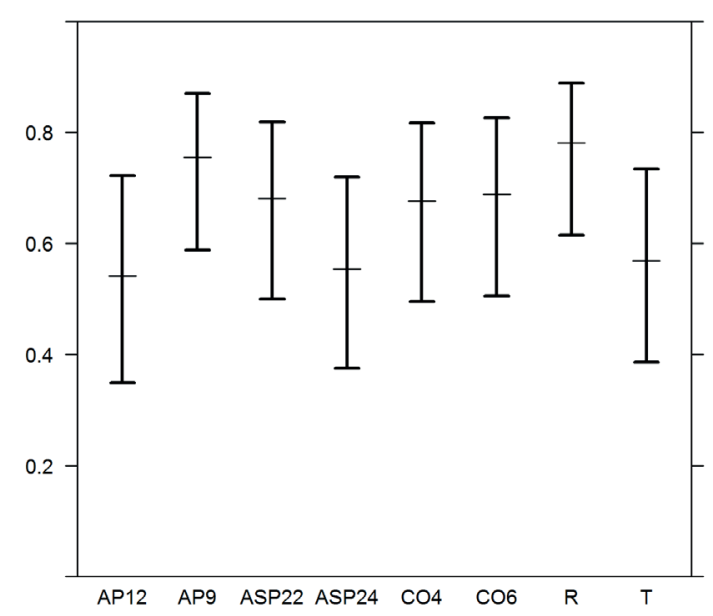

Figure 1. Damping-off (Rhizoctonia solani) incidence on soybean plants in artificially infested soil with Trichoderma populations applied using two methods: conidial suspension and inoculated oat grains. CO: populations from conventional crop; AP: populations from agropastoral system; ASP: populations from agrosilvopastoral system; R: control without Trichoderma; T: commercial strain. Bars show the $95 \%$ confidence interval. The horizontal line crossing each confidence interval bar indicates the estimated average, which is based on five replicates of two experiments for each method of soil infestation, with three consecutive sowings in each experiment. 
grains (not quantified in this study). Trichoderma has a saprophytic nature, and the oat grains serve as an organic carbon source that supports its growth, thus facilitating its survival and soil colonization (Rajput et al. 2014, Marín-Guirao et al. 2016). However, it is also possible that the organic matter provided by the oat grains release nutrients that can be used by the soybean plants, therefore enhancing their growth rate.

Three months after being applied by conidial suspension, the populations ASP24 and $\mathrm{CO} 4$ resulted in more colonies being recovered from the soil, if compared to the commercial strain. The populations AP12 and ASP22 were recovered with the same rates as the commercial strain after being applied by inoculated oat grains (Figure 3), showing that efficient native Trichoderma spp. was easily found among the populations tested.

In vitro tests showed that all native populations and the commercial strain reduced the growth of $R$. solani by volatile and non-volatile compounds, with the population CO6 showing the best results. Volatile and non-volatile compounds were the main forms of controlling $R$. solani by the Trichoderma populations tested, what is in agreement with Khalili et al. (2012). The populations ASP24 and the commercial strain also reduced the growth of the pathogen in the dual culture test (Table 1).
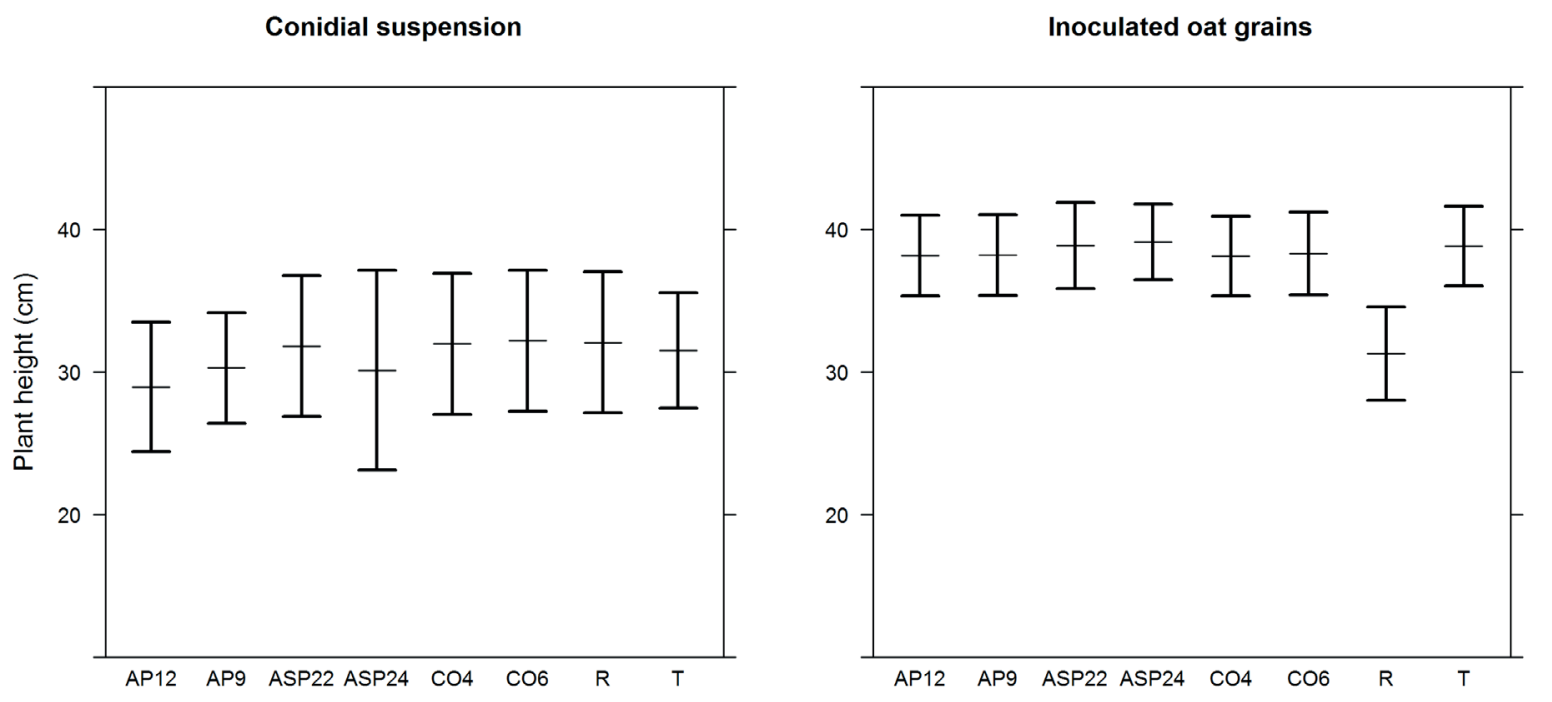

Figure 2. Growth of soybean plants in soil infested with Rhizoctonia solani, with Trichoderma populations applied through two methods: conidial suspension and inoculated oat grains. CO: populations from conventional crop; AP: populations from agropastoral system; ASP: populations from agrosilvopastoral system; R: control without Trichoderma; T: commercial strain. Bars show the $95 \%$ confidence interval. The horizontal line crossing each confidence interval bar indicates the estimated average, which is based on five replicates of two experiments for each method of soil infestation.

Table 1. Colony diameter of Rhizoctonia solani in the presence of Trichoderma populations in vitro.

\begin{tabular}{lccc}
\hline \multirow{2}{*}{ Treatment* } & \multicolumn{3}{c}{ Colony diameter $(\mathrm{mm})$} \\
\cline { 2 - 4 } & Dual culture & Volatile compounds & Non-volatile compounds \\
\hline $\mathrm{R}$ & $11.7[9.3-14.1] \mathrm{a}$ & $58.9[58.0-59.9] \mathrm{a}$ & $45.0[43.7-46.3] \mathrm{a}$ \\
CO4 & $11.0[8.5-13.4] \mathrm{ab}$ & $45.0[44.2-45.8] \mathrm{d}$ & $38.4[37.2-39.7] \mathrm{c}$ \\
CO6 & $10.7[8.3-13.1] \mathrm{ab}$ & $38.9[38.9-39.8] \mathrm{f}$ & $21.0[19.7-22.3] \mathrm{g}$ \\
AP9 & $09.3[6.9-11.7] \mathrm{abc}$ & $42.7[41.9-43.6] \mathrm{e}$ & $27.5[26.2-28.8] \mathrm{f}$ \\
AP12 & $10.0[7.6-12.4] \mathrm{abc}$ & $47.1[46.3-47.9] \mathrm{c}$ & $32.5[31.2-33.8] \mathrm{e}$ \\
ASP22 & $09.7[7.3-12.1] \mathrm{abc}$ & $42.2[41.4-43.1] \mathrm{e}$ & $41.0[39.7-42.2] \mathrm{b}$ \\
ASP24 & $09.0[6.6-11.4] \mathrm{bc}$ & $46.6[45.8-47.4] \mathrm{c}$ & $35.2[33.9-36.5] \mathrm{d}$ \\
T & $07.7[5.3-10.1] \mathrm{c}$ & $48.0[47.2-48.8] \mathrm{b}$ & $39.1[37.8-40.4] \mathrm{c}$ \\
\hline
\end{tabular}

* R: control without Trichoderma; CO: populations from conventional crop; AP: populations from agropastoral system; ASP: populations from agrosilvopastoral system; $\mathrm{T}$ : commercial strain. Confidence intervals are within brackets. Treatments followed by the same letter in the column are not significantly different at $\mathrm{p} \leq 0.05$, according to the Duncan's test. 
The in vitro results indicate that all populations were efficient by volatile and non-volatile compounds, whereas only the populations AP12 and ASP24 and the commercial strain were efficient in vivo. For this reason, in vivo tests are necessary to choose efficient Trichoderma populations for controlling plant diseases. The population ASP 24 was efficient both in the dual culture test and in in vivo tests with inoculated oat grains. As previously stated (Harman et al. 2010), effective screening and selection systems are necessary to provide highly effective strains, independently of the economic mode (commercial or on-farm) used to produce biological control agents.

Microbial populations differ in their abilities to control diseases (Harman et al. 2010). These differences were observed in the present study, as the populations that performed better in one test did not always perform well in others. However, efficient Trichoderma populations were easily found in the soils evaluated. The advantage of easier adaptation and maintenance of the biological control agent in the soil, when using native strains (Harman et al. 2010), may also be due to the greater tolerance for pesticides normally applied to the soil. This tolerance allows the native biological control agent to colonize the soil more rapidly than an exogenous biological control agent (Liu et al. 2008).

Conidial suspension

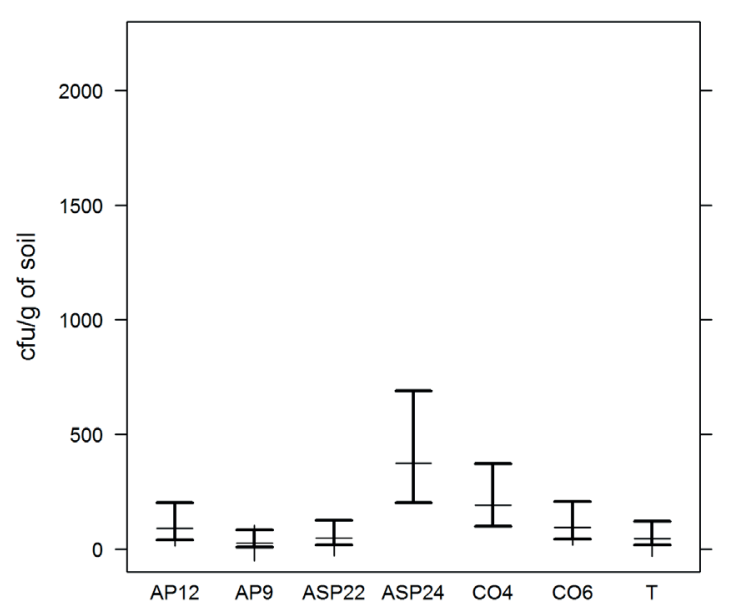

A joint analysis with all Trichoderma populations together was performed to better compare the soil infestation methods on damping-off control, plant height and soil colonization with the antagonist. Comparing the two methods for applying Trichoderma spp. to the soil, inoculated oat grains promoted a greater damping-off control, enhanced plant height and markedly increased the number of colony forming units per gram of soil after 3 months (Figure 4). Only with oat grains Trichoderma spp. enhanced plant height, when compared with the control (Figure 2). Even though the experiments with conidial suspension and inoculated oat grains were not carried out simultaneously, they were conducted in the same location, using the same soil and populations of pathogens and antagonists. Trichoderma has a saprophytic nature, and the oat grains may serve as an organic carbon source that supports its growth, facilitating its survival and establishment in the soil (Rajput et al. 2014, Marín-Guirao et al. 2016). In addition, the oat grains may have also served as a carbon source for the soybean plants.

It is also important to consider that the quantity of grains applied to the soil in this study (approximately a half ton per hectare) might make unfeasible the biological control under field conditions. However, considering the low costs of this method, when compared with others (Harman et

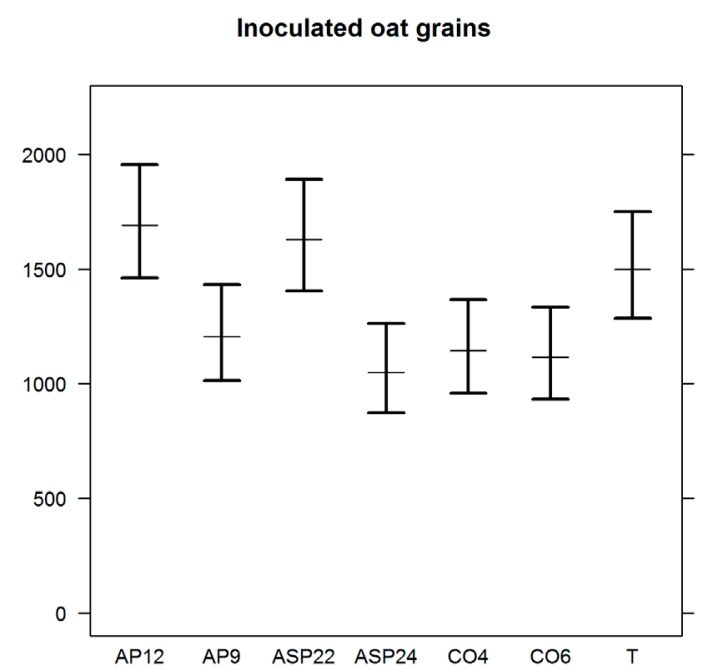

Figure 3. Colony forming units (cfu) of Trichoderma spp. recovered per gram of soil in Petri dishes with weak potato-dextrose-agar medium, at 3 months after Trichoderma populations were applied using two methods: conidial suspension and inoculated oat grains. CO: populations from conventional crop; AP: populations from agropastoral system; ASP: populations from agrosilvopastoral system; T: commercial strain. Bars show the $95 \%$ confidence interval. The horizontal line crossing each confidence interval bar indicates the estimated average, which is based on five replicates of two experiments for each method of soil infestation. 
al. 2010), and the expectation that the antagonists will survive in the soil for an extended period, applying them through an inoculated substrate is a more efficient method than through conidial suspension. Inoculated conidia have to germinate and develop on organic material in the soil prior to facing the pathogens, and the majority of conidia applied may not survive during the application or after deposition on the soil.

Trichoderma application based on an inoculated substrate has not been widely used for commercial products and, in many instances, is used for in-house or on-farm production with localized distribution (Harman et al. 2010, Woo et al. 2014). However, the efficiency of Trichoderma-based products depends on the properties of the medium in which the fungi develop (Marín-Guirao et al. 2016). The advantage of incorporating wheat bran inoculated with Trichoderma to the soil to control $R$. solani and Sclerotium rolfsii and to increase the bean yield was also observed by Elad et al. (1980).

The abundance of efficient Trichoderma strains in diversified environments may explain the abundance of commercial products found by Woo et al. (2014). This indicates the feasibility of regional surveys and tests of Trichoderma strains to allow farmers to multiply the appropriate strains
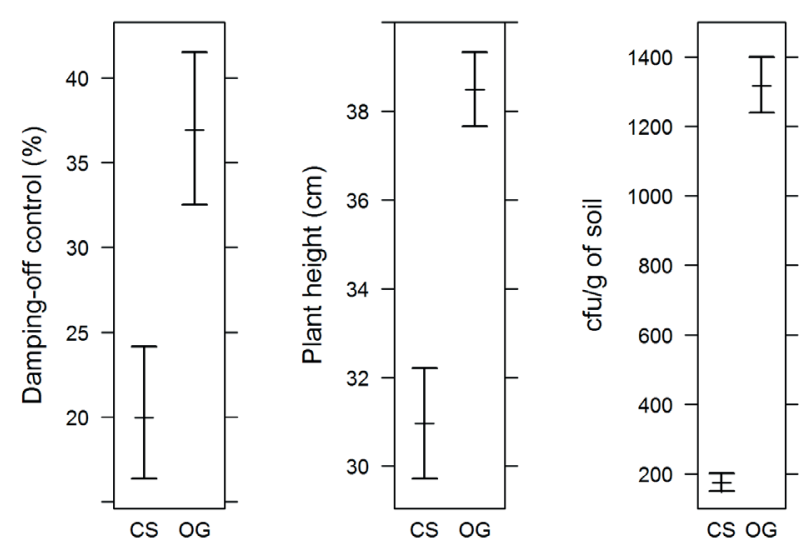

Figure 4. Results of the joint analisys for damping-off control and plant height of soybean, as well as colony forming units (cfu) per gram of soil recovered after 3 months, according to two methods of soil inoculation with Trichoderma spp.: conidial suspension (CS) and inoculated oat grains (OG). Bars show the $95 \%$ confidence interval. The horizontal line crossing each confidence interval bar indicates the estimated average, which is based on five replicates of two experiments for each method of soil infestation, with three consecutive sowings in each experiment. by themselves. Therefore, on-farm multiplication and inoculation might be advantageous strategies for controlling plant diseases that challenge crops. After carrying out tests, institutions can maintain, multiply and distribute efficient strains to farmers, according to their needs, depending on the pathogens to be controlled. Trichoderma densities in the soil could also be evaluated over several years. Although biological analysis of agricultural soil is not common, this can be done with approximately the same costs of routine chemical analysis.

\section{CONCLUSIONS}

1. Native populations of Trichoderma can be easily recovered from the soil of different production systems and are as efficient as commercial strains to control soybean damping-off, enhance soybean plant height and colonize the soil;

2. Trichoderma application in the soil through a substrate such as oat grains is a more efficient method than using conidial suspension.

\section{ACKNOWLEDGMENTS}

The authors acknowledge Dr. Paulo Justiniano Ribeiro Júnior, from the Department of Statistics of the Universidade Federal do Paraná, for helping with the statistical analysis. This study was supported by the ServiAmbi project (Scientific Cooperation Term 21500.10/0008-2, signed between Iapar and Embrapa Florestas) and also by grants from the Conselho Nacional de Desenvolvimento Científico e Tecnológico (CNPq; project number 552334/2011-1) and Coordenação de Aperfeiçoamento de Pessoal de Nível Superior (Capes).

\section{REFERENCES}

BATES, D. et al. Lme4: linear mixed-effects models using Eigen and S4. R package version 1.1-5. 2014. Available at: $<$ http://cran.r-project.org/package $=$ lme $4>$. Access on: Aug. 25, 2015.

BELL, L. W.; MOORE, A. D. Integrated crop-livestock systems in Australian agriculture: trends, drivers and implications. Agricultural Systems, v. 111, n. 1, p. 1-12, 2012.

DENNIS, C.; WEBSTER, J. Antagonistic properties of species-groups of Trichoderma: III. Hyphal interaction. Transactions of the British Mycological Society, v. 57, n. 3, p. 363-369, 1971. 
DICK, C. M.; HUTCHINSON, S. A. Biological activity of volatile fungal metabolites. Nature, v. 211, n. 5051, p. 868-868, 1966.

ELAD, Y.; CHET, I.; KATAN, J. Trichoderma harzianum: a biocontrol agent effective against Sclerotium rolfsii and Rhizoctonia solani. Phytopathology, v. 70, n. 2, p. 119121, 1980.

FERREIRA, E. B.; CAVALCANTI, P. P.; NOGUEIRA, D. A. ExpDes: experimental designs pacakge. R package version 1.1.2. 2003. Available at: <http://cran.r-project.org/ package $=$ ExpDes $>$. Access on: Jun. 10, 2016.

GARBISU, C.; ALKORTA, I.; EPELDE, L. Assessment of soil quality using microbial properties and attributes of ecological relevance. Applied Soil Ecology, v. 49, n. 1, p. 1-4, 2011.

GROSCH, R. et al. Fungal antagonists of the plant pathogen Rhizoctonia solani: selection, control efficacy and influence on the indigenous microbial community. Mycological Research, v. 110, n. 12, p. 1464-1474, 2006.

HARMAN, G. E. et al. Changing models for commercialization and implementation of biocontrol in the developing and the developed world. Plant Disease, v. 94, n. 8 , p. 928-939, 2010.

HOTHORN, T.; BRETZ, F.; WESTFALL, P. Simultaneous inference in general parametric models. Biometrical Journal, v. 50, n. 3, p. 346-363, 2008.

JANVIER, C. et al. Soil health through soil disease suppression: which strategy from descriptors to indicators? Soil Biology and Biochemistry, v. 39, n. 1, p. 1-23, 2007.

KHALILI, E. et al. Biological control of rice brown spot with native isolates of three Trichoderma species. Brazilian Journal of Microbiology, v. 43, n. 1, p. 297-305, 2012.

KINSBURSKY, R. S.; WEINHOLD, A. R. Influence of soil on inoculum density-disease incidence relationships of Rhizoctonia solani. Phytopathology, v. 78, n. 2, p. 127130, 1988.

LARKIN, R. P. Soil health paradigms and implications for disease management. Annual Review of Phytopathology, v. 53, n. 1, p. 199-221, 2015.

LIU, B.; GLENN, D.; BUCKLEY, K. Trichoderma communities in soils from organic, sustainable, and conventional farms, and their relation with southern blight of tomato. Soil Biology \& Biochemistry, v. 40, n. 5, p. 11241136, 2008.
LORITO, M. et al. Translational research on Trichoderma: from 'omics to the field. Annual Review of Phytopathology, v. 48 , n. 1, p. 395-417, 2010.

MARÍN-GUIRAO, J. I. et al. Effect of Trichoderma on horticultural seedlings' growth promotion depending on inoculum and substrate type. Journal of Applied Microbiology, v. 121, n. 4, p. 1095-1102, 2016.

MISCHKE, S. A quantitative bioassay for extracellular metabolites that antagonize growth of filamentous fungi, and its use with biocontrol fungi. Mycopathologia, v. 137, n. 1, p. 45-52, 1997.

R CORE TEAM. $R$ : a language and environment for statistical computing. 2015. Available at: $<$ http://www.rproject.org/>. Access on: Jun. 10, 2016.

RAJPUT, A. Q.; KHANZADA, M. A.; SHAHZAD, S. Effect of different substrates and carbon and nitrogen sources on growth and shelf life of Trichoderma pseudokoningii. International Journal of Agriculture \& Biology, v. 16, n. 5, p. 893-898, 2014.

SARKAR, D.; ANDREWS, F. LatticeExtra: extra graphical utilities based on Lattice. R package version 0.6-26. 2013. Available at: <http://cran.r-project.org/ package=latticeExtra $>$. Access on: Aug. 25, 2015.

SINGH, A. et al. Optimal physical parameters for growth of Trichoderma species at varying $\mathrm{pH}$, temperature and agitation. Virology \& Mycology, v. 3, n. 1, p. 1-7, 2014.

VARGAS GIL, S.; PASTOR, S.; MARCH, G. J. Quantitative isolation of biocontrol agents Trichoderma spp., Gliocladium spp. and actinomycetes from soil with culture media. Microbiological Research, v. 164, n. 2, p. 196-205, 2009.

VENABLES, W.; RIPLEY, B. Modern applied statistics with S. 4. ed. New York: Springer Netherlands, 2002.

VERMA, M. et al. Antagonistic fungi, Trichoderma spp.: panoply of biological control. Biochemical Engineering Journal, v. 37, n. 1, p. 1-20, 2007.

WELLER, D. M. et al. Microbial populations responsible for specific soil suppressiveness to plant pathogens. Annual Review of Phytopathology, v. 40, n. 1, p. 309348, 2002.

WOO, S. L. et al. Trichoderma-based products and their widespread use in agriculture. The Open Mycology Journal, v. 8, n. 1, p. 71-126, 2014. 